\title{
Accountability by design? Exploring design characteristics of corporate social
sponsibility standards of corporate social
responsibility standards
}

\begin{abstract}
Purpose - While corporate social responsibility (CSR) standards are amongst the most widely adopted instruments for supporting firms in becoming more accountable, firms who adopt them frequently fail to comply. In this context, the purpose of this study is to explore to what extent CSR standards are designed for accountability. In the analysis, this paper investigates design characteristics related to accountability across different standard types, namely, principle-based, reporting, certification and process standards.

Design/methodology/approach - This study reviews the design characteristics of 50 CSR standards in a systematic and comparative fashion. This paper combines qualitative deductive coding with exploratory quantitative analyses methods to elucidate structural variance and patterns of accountability-related design characteristics across the sample.

Findings - This study finds that the prevalence of design characteristics aimed at fostering accountability varies significantly between different types of standards. This paper identifies three factors related to the specific purpose of any given standard that explain this structural variation in design characteristics, namely, implementability, comparability and measurability.

Practical implications - Non-compliance limits the effectiveness and legitimacy of CSR standards. The systematic exploration of patterns and structural variation in design characteristics that promote accountability may provide valuable clues for the design of more effective CSR standards in the future.

Social implications - Better understanding the role of design characteristics of CSR standards is critical to ensure they contribute to greater corporate accountability.

Originality/value - This study strives to expand the current understanding of the design characteristics of CSR standards beyond individual cases through a systematic exploration of accountability-related design characteristics across a larger sample.
\end{abstract}

Keywords Corporate social responsibility, Mixed-method design, Accountability mechanisms, CSR standards, Standard design

Paper type Research paper

(C) Norma Schönherr, Heike Vogel-Pöschl, Florian Findler and Andre Martinuzzi. Published by Emerald Publishing Limited. This article is published under the Creative Commons Attribution (CC BY 4.0) licence. Anyone may reproduce, distribute, translate and create derivative works of this article (for both commercial \& non-commercial purposes), subject to full attribution to the original publication and authors. The full terms of this licence may be seen at http://creativecommons.org/ licences/by/4.0/legalcode

Data leading to this publication was generated in the context of the GLOBAL VALUE project. GLOBAL VALUE was co-funded by the European Union Seventh Framework Programme under grant agreement no 613295 .

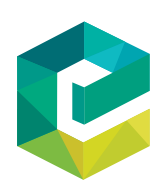

Sustainability Accounting, Management and Policy Journal Vol. 13 No. 1, 2022 
SAMPJ

13,1

\section{Introduction}

Firms affect billions of people across the world through their products, operations and value chains. Increasingly, they have also been recognized as a major driver of sustainable development (Martinuzzi and Schönherr, 2019; Schönherr et al., 2017; Lenssen and Blowfield, 2012; Dyllick and Muff, 2016). However, in response to the global economic, financial and social crises that have emerged since 2008/2009, public trust in the ability of businesses to drive positive social change is diminishing (Bies, 2014; Curran and Eckhardt, 2020; Gardels and Berggruen, 2017; Witt, 2019). In response, many firms have taken strides towards integrating corporate social responsibility (CSR) into their business operations (Martinuzzi and Krumay, 2013; Pivot Goals, 2017; Schönherr et al., 2017). For instance, 90\% of S\&P 500 Index companies set sustainability-related management objectives and published CSR reports in 2019 (Peterson et al., 2020).

CSR standards have emerged as one of the most prevalent instruments for supporting firms in becoming more accountable for the social and environmental sustainability of their operations (Blankenbach, 2016; Christensen et al., 2019; Derkx and Glasbergen, 2014; Leipziger, 2017, 2003). Some well-known examples of such standards include the United Nations Global Compact (Arevalo et al., 2013; Rasche, 2009) or the ISO 14000 families of environmental management standards (Hahn and Weidtmann, 2016; Heras-Saizarbitoria and Boiral, 2013; Popa and Dabija, 2019). However, there is evidence pointing towards the frequent failure of firms to implement CSR standards effectively (Michelon et al., 2016; Fransen and Kolk, 2007).

Hitherto, firms that adopted CSR standards were blamed for failing to achieve compliance (Banerjee, 2011; Ählström, 2010; Dietz et al., 2019). However, there is mounting evidence that the design characteristics of the CSR standards themselves, specifically the accountability mechanisms they contain, should be considered as an antecedent of later compliance or non-compliance (Simpson et al., 2012; Wijen, 2014; Milne and Gray, 2013; Fraser et al., 2020). Nevertheless, the design characteristics of CSR standards remain underresearched (Reinecke et al., 2012; Behnam and MacLean, 2011). This gap is becoming increasingly relevant in light of the growing importance of voluntary CSR standards in international CSR governance (Albareda and Waddock, 2017; Scherer and Palazzo, 2011; Waddock, 2008).

Extant studies (Slager et al., 2012; Windolph et al., 2014; Zinenko et al., 2015; Rasche, 2009; Behnam and MacLean, 2011; Grimm et al., 2020) on the design characteristics of CSR standards have largely consisted of (multi) case study designs and conceptual contributions. They provide important insights into the design characteristics of individual standards (Zinenko et al., 2015; Vigneau et al., 2015; Schuler and Christmann, 2011; Delmas and Montes-Sancho, 2011; Grimm et al., 2020) and/or theorize about the broader relevance of design characteristics to accountability (Wijen, 2014; Haack and Schoeneborn, 2015). An exploration of patterns and variance in design characteristics across a larger sample of CSR standards is still wanting, however.

The purpose of this paper is to explore to what extent CSR standards are designed for accountability. We review the design characteristics of 50 CSR standards in a systematic and comparative fashion. In doing so, we elucidate patterns in accountability mechanisms across a plethora of extant CSR standards. On the one hand, this approach serves to explore more widely the reliability of the results yielded by previous work on the design characteristics of CSR standards. On the other hand, we strive to build on existing work by expanding the current understanding of the design characteristics of CSR standards beyond individual cases. 
We find that different types of standards display significant variations in the accountability mechanisms they contain. Maybe counter-intuitively, the type of standard setter does not seem to have a bearing on the degree to which standards promote accountability by design. Our data suggest that there are different design strategies standard-setting initiatives may pursue when it comes to accountability mechanisms. Firstly, some standards focus on "comparability", i.e. the degree to which a standard enables comparisons across time and across adopters. Secondly, standards can be designed to enhance "measurability", i.e. the degree to which evaluation criteria and performance metrics are well-specified and quantifiable. The third strategy prioritizes "implementability", i.e. the degree to which guidance on effective implementation is available to support adopters in achieving compliance. Consideration of this structural variance is relevant because it may provide valuable clues for the design of future CSR standards and can inform more targeted research on their effectiveness.

The remainder of this paper is organized as follows: Section 2 provides a review of the literature on CSR standards, contextualizes and elaborates on the design characteristics of CSR standards. Section 3 presents the research design of the present study and provides a description of the sampling process, coding strategy and data analysis methods used. Section 4 provides an overview of the main findings of the study, focusing specifically on the structural variation in the design characteristics of CSR standards. The findings are discussed and linked back to the literature in Section 5 . We conclude by providing an outlook on opportunities for future comparative research on the design characteristics of CSR standards.

\section{Literature review}

\subsection{Conceptualising corporate social responsibility standards from a neo-institutional perspective}

This study applies a neo-institutional lens (Brammer et al., 2012) and conceptualizes CSR standards as part of the "set of legal, cultural and institutional arrangements that determine what [... . corporations can do, who controls them, [and] how this control is exercised" (Blair, 1995, p. 19). From a neo-institutional perspective, CSR standards are viewed as a non-legal ("soft") form of regulation for firm behaviour (Scherer and Palazzo, 2011; de Bakker et al., 2019). Voluntary in nature, they address sustainability issues, particularly in transnational arenas beyond the jurisdiction of individual nation-states (Potts et al., 2014; Schleifer, 2019; Schleifer et al., 2019; Fransen et al., 2019). The adoption of CSR standards has become ubiquitous amongst firms (Perego and Kolk, 2012; Schönherr et al., 2019) and may even reach quasi-mandatory status when a standard comes to dominate a market or industry (Blankenbach, 2016; Ponte, 2012; Sippl, 2015).

More specifically, Gilbert et al. (2011, p. 24) define CSR standards as "voluntary predefined rules, procedures and methods to systematically assess, measure, audit and/or communicate the social and environmental behaviour and/or performance of firms". An essential function of CSR standards is to define socially and environmentally desirable practices and outcomes and to provide some sort of accountability of firms vis-à-vis stakeholders for their actions and omissions with regard to these practices and outcomes (Bebbington, 2009; Behnam and MacLean, 2011; Schons and Steinmeier, 2016).

To effectively enhance accountability, institutional arrangements need to be designed in a way that imposes credible requirements on firm behaviour and ensures that adopters will generally fulfil these requirements (Bromley and Powell, 2012; Grimm et al., 2020). Therefore, institutional arrangements require accountability mechanisms, which safeguard that the "rules of the game" are complied with. In other words, the design characteristics of 
SAMPJ

13,1

the institutions that govern firm behaviour - CSR standards in our case - are an important predictor of whether they are adopted only in form or also in function (Behnam and MacLean, 2011; Wijen, 2014; Rasche, 2009). By adopting this perspective, we look beyond the characteristics and behaviour of the firm and focus instead on the antecedents of accountability that are applicable across firms.

\subsection{Designing corporate social responsibility standards for accountability}

By accountability mechanisms, we mean those parts of the institutional arrangement which ensure that rules are complied with (Behnam and MacLean, 2011; Vigneau et al., 2015; Wijen, 2014). When legal sanctions are absent, as is the case for CSR standards because of their fundamentally voluntary nature, other accountability mechanisms are essential to ensure effective implementation of institutional arrangements (O'Dwyer et al., 2011; Perego and Kolk, 2012). While such accountability mechanisms do not provide full control over the potential opportunistic behaviour of adopters, they are nevertheless considered essential for incentivizing compliance (Wijen, 2014). There is a general consensus in the literature that CSR standards may vary considerably in terms of how accountability mechanisms are reflected in their design (Gilbert et al., 2011; Reinecke et al., 2012; Wiengarten et al., 2016; Rasche, 2014). This literature also distinguishes several specific design characteristics geared towards enhancing accountability.

Firstly, this includes guidance on effective implementation (Rasche, 2009). Supplementing a standard with guidance on its effective implementation is primarily geared towards addressing the problem of lack of capacity amongst corporate adopters (Schönherr et al., 2019), who may not have the knowledge, skills or experience required to interpret a standard in the spirit in which it was conceived or to build the organizational structures needed to implement it fully (Wijen, 2014). Such guidance may take a variety of forms, ranging from a checklist or written "implementation manuals" to training and even individualized intensive consultancy services for adopters. Many standard setters also provide best practice examples or build peer communities to ensure that adopters are fully aware of how to best implement the requirements of a standard (Komives and Jackson, 2014).

Secondly, a large majority of CSR standards include some form of assessment to check whether adopters comply with the requirements of the standard. However, the specificity of the metrics of such assessments may vary. On the one hand, standards may allow for narrative accounts of compliance, which are highly flexible and provide the opportunity to explore detailed and unstructured data of all kinds (Dalal-Clayton and Bass, 2011). On the other hand, highly specific indicator-based assessments are considered the most useful approach to achieving measurable, transparent and comparable results and consequently, they are a better foundation for accountability (Esteves et al., 2012; de RIDDER et al., 2007).

Thirdly, the sustainability issues covered by CSR standards are highly diverse, spanning a range from working conditions to biodiversity conservation. Concrete practices and their contribution to adequately addressing these issues are not always clear and/or observable (Tharani, 2019). For adopters, this poses the risk of not paying the required attention to issues, which may be perceived as fuzzy (Rasche, 2009). Standards that systematically specify salient issues, prescribe adequate practices and provide clear evaluation criteria for assessing compliance are, therefore, more likely to be implemented as intended. As Wijen (2014: 308) states: "detailed codification offers clear guidance and limits the room for divergent interpretation, thereby reducing ambiguity and uncertainty".

Fourthly, and closely related to the standardization of sustainability issues, is the extent to which standards prescribe adequate practices and provide clear evaluation criteria for 
assessing compliance (Wijen, 2014; Bebbington, 2009). For instance, Grimm et al. (2020) show that compliance with a standard can be substantially influenced by the evaluative criteria used by the standard-setter. Such criteria define what is considered successful implementation and provide a yardstick against which the performance of an adopter can be measured (Tharani, 2019). Consequently, the specification in a standardized way of sustainability issues and evaluation criteria play an important role in laying out what is actually required of corporate adopters and ensuring that rules are specific, concrete and not easily subverted (Behnam and MacLean, 2011).

Fifthly, the verification of compliance - frequently considered under the terms auditing, in relation to management standards (Fraser et al., 2020; Pruett et al., 2005) or assurance, in relation to reporting standards (O'Dwyer et al., 2011; Perego and Kolk, 2012) - is arguably one of the best-documented accountability mechanisms in the scholarship on CSR standards. The increasing uptake of verification practices for greater accountability stems from classical accounting, where financial auditing has traditionally provided greater confidence in the accuracy and robustness of compliance claims (Milne and Gray, 2013). Literature on verification distinguishes first, second and third-party verification of accountability claims. In the space of voluntary CSR standards, however, the effectiveness of extant verification measures is disputed (Pruett et al., 2005; Fransen and Kolk, 2007; Perego and Kolk, 2012), even though third-party verification is generally considered one of the strongest accountability mechanisms available (TERWINDT and ARMSTRONG, 2019). Therefore, some standards focus on improving verification, rather than setting CSR performance requirements per se. For instance, this is the case for the AA 1000 standard by AccountAbility (Rasche and Seidl, 2019; Rasche, 2014)

Sixthly, benchmarking can complement verification by auditors as a softer accountability mechanism. Benchmarking is intended as a peer control mechanism whereby other stakeholders are enabled to compare information and performance scores against other standard adopters, standard requirements or best practices (van Kersbergen and van Waarden, 2004). Some standards particularly stress benchmarking as a mechanism for continuous improvement, both of the compliance of adopters and of the standard itself (e.g. GLOBAL G.A.P., Hachez and Wouters, 2011).

Finally, for some CSR standards, the award of a label or certificate (on a product, facility, firm or supply chain) is the main purpose. However, certification options, both mandatory and voluntary, can also be used as an inducement for adopting firms to better comply with standard requirements (Chkanikova and Sroufe, 2020; Christmann and Taylor, 2006). For instance, the B Impact Assessment Standards can be independently used by firms to assess and improve their sustainability performance (Villela et al., 2019). However, a minimum score is needed to qualify for certification - which, in turn, provides a host of new benefits and additional legitimacy to adopters. In turn, certification can be withheld or firms can be de-listed from public records of certificate holders, thus functioning as a punishment for non-compliance (Feng et al., 2016; Overdevest, 2010; Richards et al., 2017).

\subsection{Classifying corporate social responsibility standard types and standard setters}

The extant literature notes that there is a substantive structural variation amongst the plethora of existing CSR standards (Marx, 2013; Fransen et al., 2019; Reinecke et al., 2012). Consequently, several attempts have been made to develop useful taxonomies and classification systems (Behnam and MacLean, 2011; Rasche, 2009; Brunsson et al., 2012; Timmermans and Epstein, 2010). This is a difficult endeavour, however, not least because new standards tend to incorporate elements of their predecessors to form new hybrids, which defies any attempt to develop mutually exclusive categories (Rasche, 2014). 
SAMPJ

13,1

One vector along which CSR standards can be classified is the main purpose for which they are developed (Schönherr et al., 2019). This is useful because the purpose of a CSR standard predetermines the specific design characteristics required to attain that purpose. Drawing on Rasche (2014), we distinguish four types of standards.

Firstly, principle-based standards are amongst the longest-established CSR standards, with the first examples appearing as early as the 1970s. As their name suggests, they strive to formulate basic principles of responsible corporate conduct, sometimes loosely coupled with a list of desired outcomes (Rasche, 2009, 2014). Examples of this type of standard are the AA1000 AccountAbility Principles Standard (Rasche and Seidl, 2019), the OECD Guidelines for Multinational Enterprises (Reinert et al., 2016; Liberti, 2012) or the Caux Round Table Principles for Moral Capitalism (Carroll, 2013).

Secondly, certification standards aim to monitor design, production and trade practices with a view to awarding labels (for products) or certificates (for facilities or entire firms) that firms can use to signal to stakeholders (e.g. consumers, supply chain partners, investors) that they conform to ethical, environmental and social requirements (Boiral and Gendron, 2011; Richards et al., 2017). The Forest Stewardship Council (Overdevest, 2010; Sippl, 2015), SA 8.000 (Sartor et al., 2016), as well as the Fairtrade Standards (Schuler and Christmann, 2011), are widely adopted examples of this standard type.

Thirdly, some standards focus on processes and management practices related to CSR, without awarding labels or certificates. They are geared towards enabling adopters to create appropriate governance and management structures for the discharge of their social and environmental responsibilities and are frequently accompanied by guidance on best practices (Zinenko et al., 2015; Rasche, 2014). ISO 26000 (Hahn, 2013; Popa and Dabija, 2019) and the Natural Capital Protocol (Whitaker, 2018) are apt illustrations of this standard type.

Fourthly, the increasing adoption of non-financial reporting by firms has led to the emergence of reporting standards (Burritt and Schaltegger, 2010; Tschopp and Nastanski, 2014). These standards aim to harmonize reporting practices across firms, sectors and regions to generate more comparable information that can be used by stakeholders to hold firms accountable (in the same way that accounting standards provide relevant information enabling shareholders to hold managers accountable) (Christensen et al., 2019; Milne and Gray, 2013). The Global Reporting Initiative's sustainability reporting standards (Vigneau et al., 2015; Pope and Lim, 2020) and the International Integrated Reporting Council's Integrated Reporting Framework (Kannenberg and Schreck, 2019; Vaz et al., 2016) are arguably the most prominent examples of this type.

A second vector along which CSR standards may be classified is the type of standardsetting organization or initiative (Potts et al., 2014; Gilbert et al., 2011; Reinecke et al., 2012). The organizations and initiatives that develop CSR standards may take a variety of different forms and involve different stakeholder groups (de Bakker et al., 2019; Christmann and Taylor, 2002). Several studies suggest that the type of standard setter (also termed "sponsor", Carmin et al., 2003) influences the inclusivity of the standard design process and consequently the design characteristics of the final published standard (Prakash and Potoski, 2007; Terlaak, 2007; Tschopp and Nastanski, 2014). For instance, some authors have argued that standard-setting processes spearheaded by business (including business associations, business networks and consultancies) tend to be limited by their focus on ensuring that issues relevant to the firms themselves are reflected in the design of the standard, rather than issues of societal and environmental relevance (Carmin et al., 2003; Schuler and Christmann, 2011). This, some scholars argue, has resulted in a "race to the bottom" where accountability mechanisms are concerned. Standards advanced by businesses, they argue, compete for adopters by lowering the bar relative to more stringent 
standards provided by other types of standard setters such as non-profit or international organizations (Reinecke et al., 2012; Fransen et al., 2019).

For the purposes of this study, we distinguish between five different types of standardsetting initiatives (Table 1). Business-led initiatives include for-profit organizations as well as organizations exclusively representing the interests of firms (e.g. business clubs and business associations). In contrast, non-profit organizations (NGOs) cover all non-profit and non-governmental organizations, except those exclusively representing business interests. The third type of standard setters is international organizations (IGOs) that differ from NGOs in that they are comprising public, inter-governmental initiatives. Increasingly, standards are developed by multi-stakeholder initiatives (MSIs). Such initiatives involve two or more different types of stakeholders (e.g. business, civil society, governments or IGOs). Finally, the above-mentioned types of standard setters may also partner to develop new standards for a limited period while maintaining their independence as separate entities. We call such initiatives partnership initiatives.

\section{Research design and methods}

The research design presented hereafter is geared towards an open-ended exploration of the design characteristics in CSR standards. More specifically, it aims to provide insights into the degree to which CSR standards differ from each other regarding the accountability mechanisms they contain. For this purpose, we apply a mixed methods research design drawing on an inventory of 50 CSR standards (Grafton et al., 2011). To our knowledge, this is the first exploratory comparative review covering such a large sample of CSR standards.

\subsection{Sample}

We inventoried extant CSR standards by following a purposive sampling approach. This qualitative approach is particularly useful for achieving a degree of representativeness and comparability across a population that is difficult to define in its totality (Teddlie and Yu, 2017). Given that, to our knowledge, a complete database of CSR standards does not exist,

\begin{tabular}{|c|c|c|}
\hline Type & Definition & Examples \\
\hline Business & $\begin{array}{l}\text { Includes for-profit organizations (incl. consultancies) } \\
\text { as well as organizations exclusively representing the } \\
\text { interests of for profit-organizations (such as business } \\
\text { clubs or business associations) }\end{array}$ & $\begin{array}{l}\text { AccountAbility and business social } \\
\text { compliance initiative }\end{array}$ \\
\hline Non-profit & Includes non-governmental and non-profit & Oxfam international and fairtrade \\
\hline organization & organizations (except for those exclusively & labelling organizations \\
\hline$(N G O)$ & representing the interests of for-profit organizations) & International \\
\hline $\begin{array}{l}\text { International } \\
\text { organization } \\
\text { (IGO) }\end{array}$ & $\begin{array}{l}\text { Includes international, intergovernmental } \\
\text { organizations }\end{array}$ & $\begin{array}{l}\text { United Nations, international labour } \\
\text { organization }\end{array}$ \\
\hline $\begin{array}{l}\text { Multi- } \\
\text { stakeholder } \\
\text { initiative (MSI) }\end{array}$ & $\begin{array}{l}\text { Includes initiatives and organizations involving two } \\
\text { or more different types of stakeholders (such as } \\
\text { business, civil society, governments or international } \\
\text { organizations) }\end{array}$ & $\begin{array}{l}\text { Global reporting initiative and } \\
\text { ethical trading initiative }\end{array}$ \\
\hline $\begin{array}{l}\text { Partnership } \\
\text { initiative (PI) }\end{array}$ & $\begin{array}{l}\text { Includes partnerships of at least two organizations } \\
\text { from amongst the above-mentioned sponsor types, } \\
\text { who collaborate on a specific standard-setting project } \\
\text { but also continue to exist as separate entities }\end{array}$ & Gender equality principles initiative \\
\hline
\end{tabular}

Accountability by design

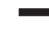


SAMPJ

13,1

\section{8}

we compiled a dedicated inventory of some 50 standards for the purpose of this study (Table 2). The inventory drew on three distinct sources:

(1) we reviewed the academic literature on CSR standards (Table 1),

(2) we consulted relevant databases containing CSR standards and standard-setting initiatives, specifically the Multi-Stakeholder Initiatives Database (https://msidatabase.org/) and the partnerships for the sustainable development goals (SDGs) global registry of voluntary commitments and multi-stakeholder partnerships (https://sustainabledevelopment.un.org/partnerships/) and

(3) we drew on a crowdsourced inventory of CSR standards and tools compiled in the course of the EU funded research project GLOBAL VALUE (see https://www. global-value.eu/navigator.php; Vogel-Pöschl et al., 2020).

The CSR standards included in the final sample were selected to generate the maximum variety of individual cases to enable a rich and fruitful comparative assessment (Teddlie and Tashakkori, 2010). More specifically, we selected CSR standards offered by different types of standard setters (business, non-profit organizations, international organizations and multi-stakeholder and partnership initiatives) and CSR standards of all four standard types (principle-based, certification, process and reporting standards). To ensure a basic level of comparability, we included only standards that are applicable at the international level (i.e. no standards specifically developed for a single national or regional context), standards that can be adopted and/or implemented by firms directly (i.e. no ratings or indices) and we avoided standards that are only applicable to one type of product (notwithstanding, some sector-specific standards were included). In addition, we focused on non-proprietary standards to ensure a comparable level of access to information.

The sample contains CSR standards first released as early as the 1970s (e.g. the ILO's labour standards) but also includes recently issued exemplars that have received significant attention (e.g. the Natural Capital Coalition's Natural Capital Protocol). As many standards are regularly revised and updated, we consistently chose the latest available version of each CSR standard for our research.

\subsection{Coding strategy}

The CSR standards were exclusively attributed to one of the four standard types based on their stated purpose as well as to one category of standard-setter based on the stated organization or initiative that issues the standard (Table 1). The coding for these two variables was binary ( 1 - part of the group; 0 - not part of the group).

The individual standards were then deductively coded for the seven accountability mechanisms described in the literature review (Table 3), namely, the guidance on effective implementation, the specificity of metrics, the standardization of issues covered, the standardization of evaluation criteria, the verification mechanisms, benchmarking and the availability of certification options. We reviewed the standard texts as well as the supporting documentation and used the information contained therein to build our coding matrix.

We used magnitude coding to assign distinct levels of intensity to each accountability mechanism (Saldaña, 2016). This type of coding affixes an additional alphanumeric code to an established qualitative category, and thus allows the data to be transformed in such a way that the codes can be used for quantitative statistical analyses. For our purposes, we coded our data along a five-point scale, with 1 indicating the lowest and 5 indicating the 


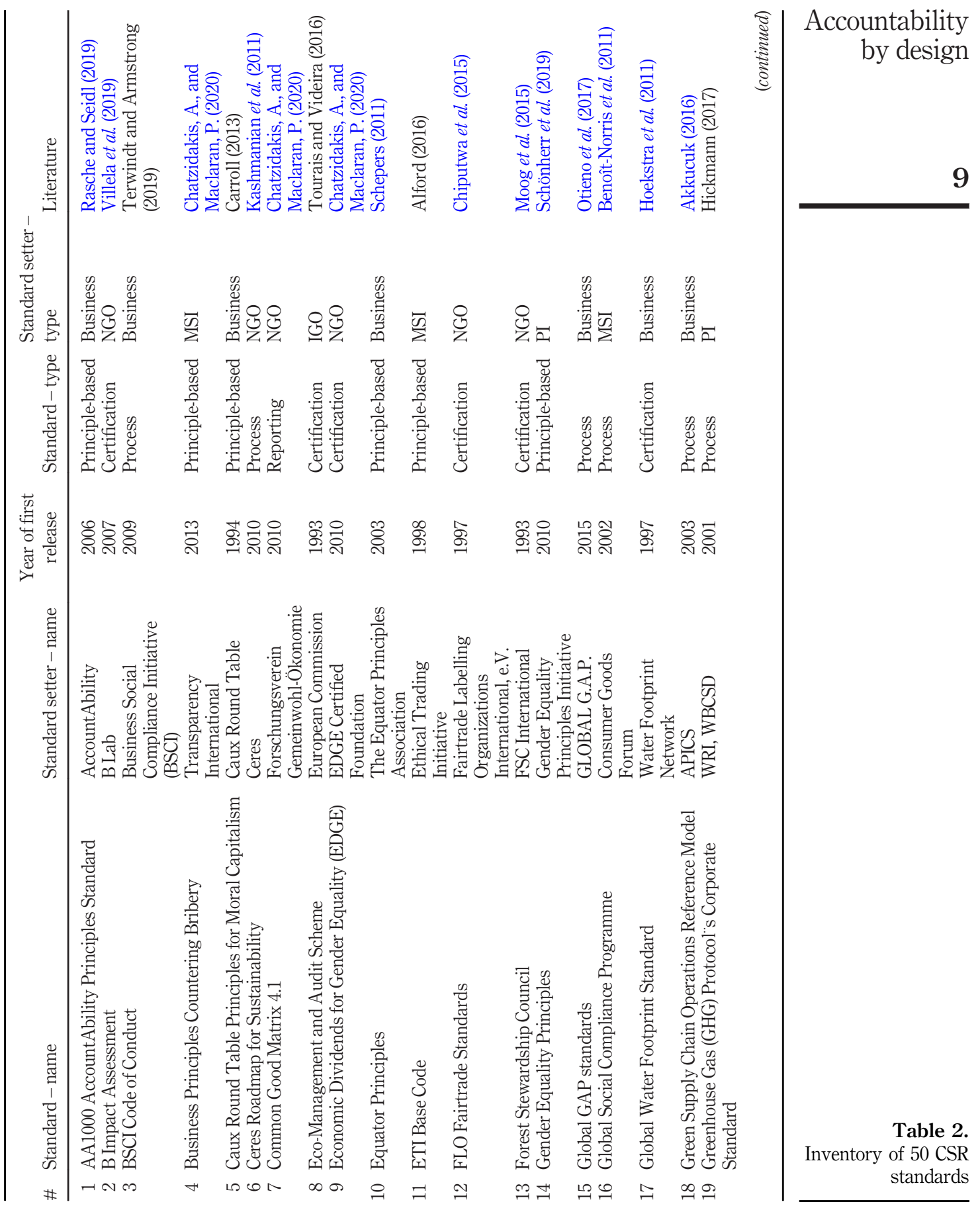




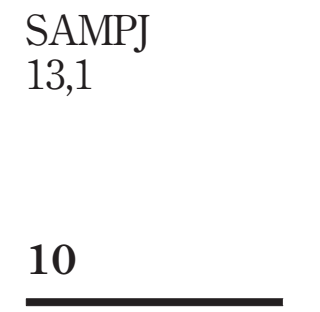

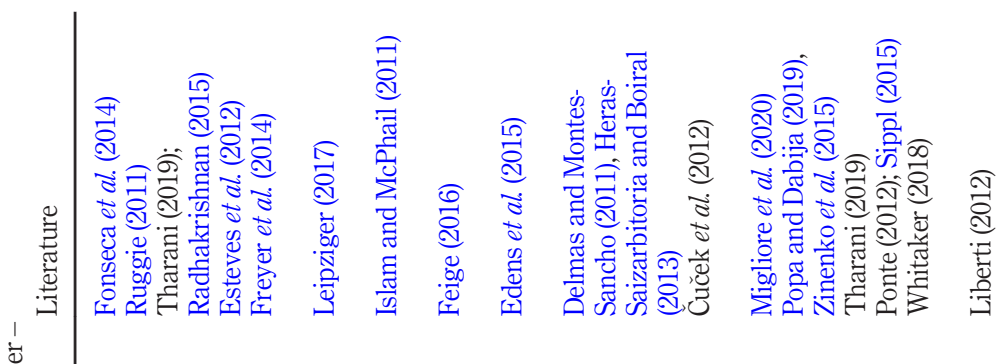

胥

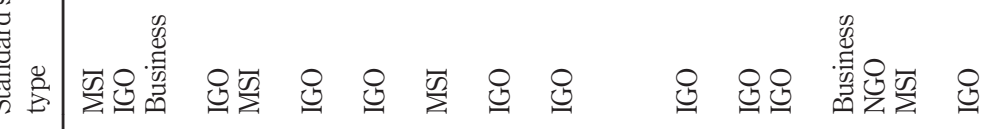

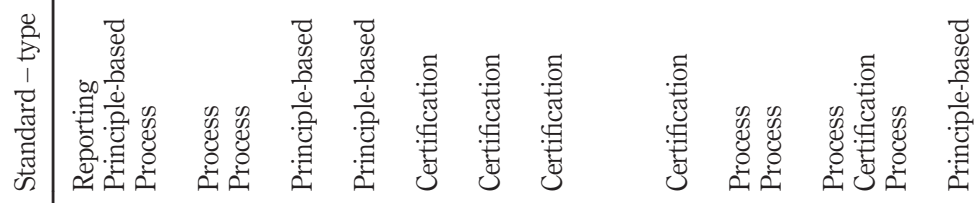

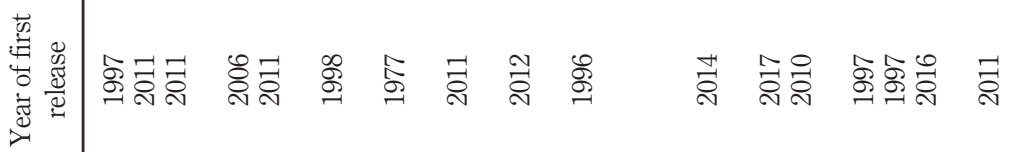

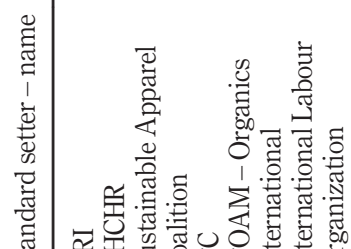

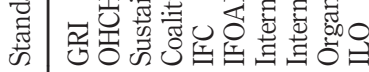

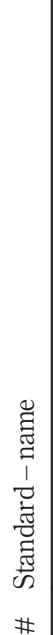

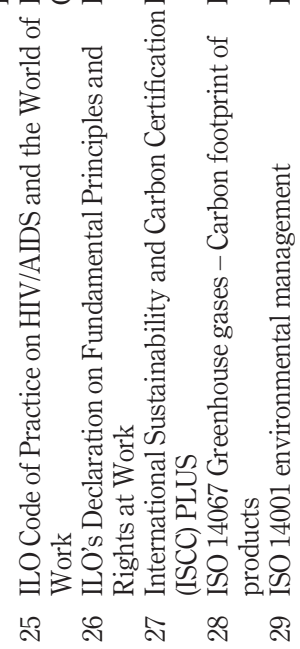

苞.

䒯苞总

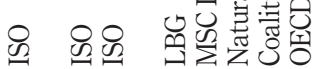

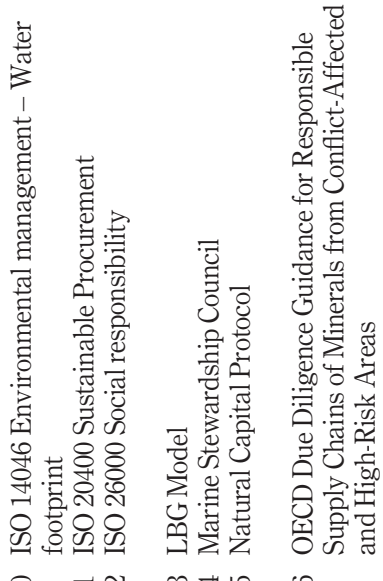




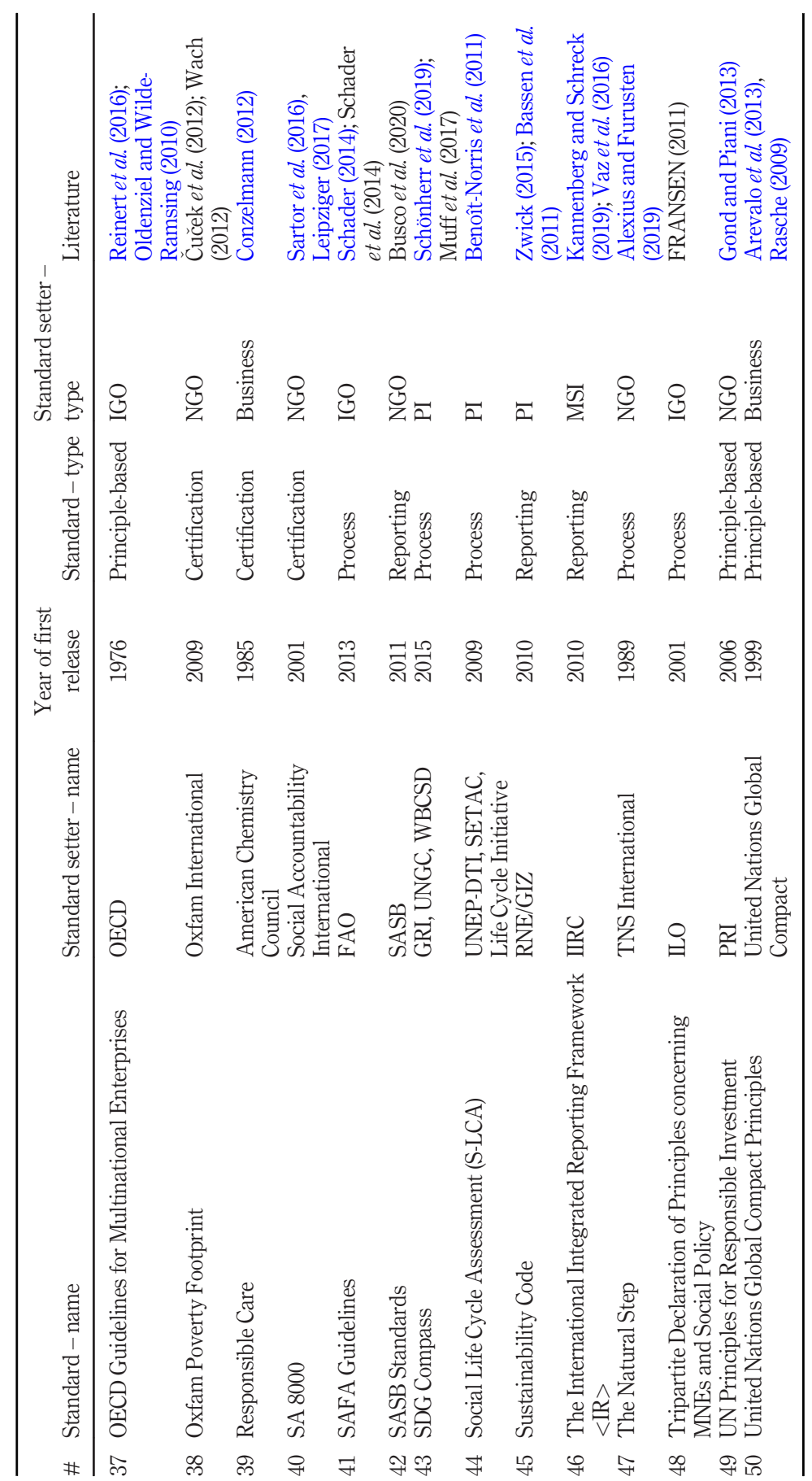
Accountability
by design 
SAMPJ

13,1

12

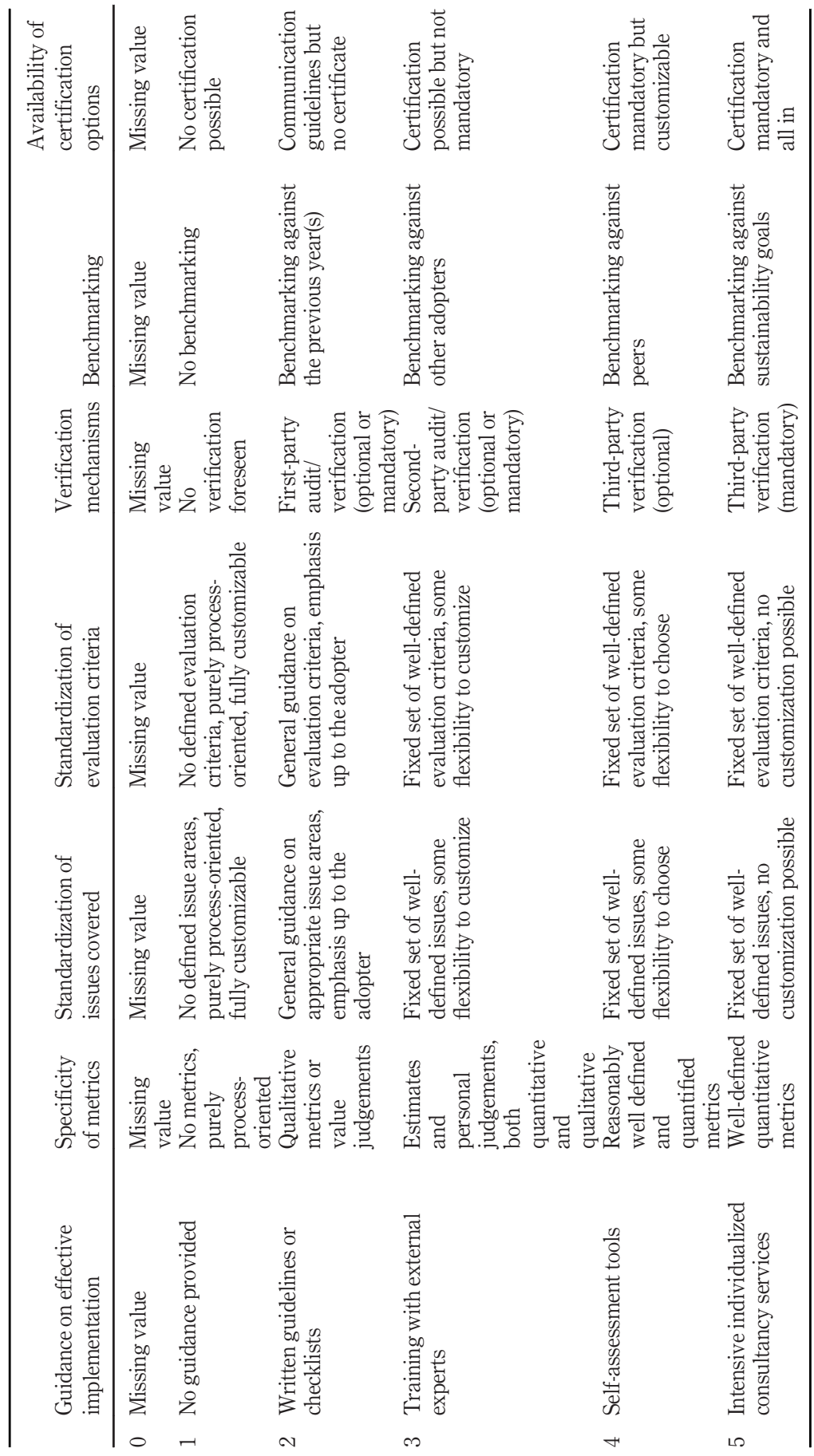

Table 3.

Codebook including design

characteristics and assigned levels of intensity 
highest level of intensity for each accountability mechanism (Saldaña, 2016). Missing values were coded as 0 (Table 3 ).

For each accountability mechanism, all 50 standards were independently coded by two researchers. In the case of divergent coding, the respective cases were discussed between the coders until intercoder agreement was achieved. The resulting coding matrix contains a distinct design profile for each CSR standard and was used as a basis for the comparative assessment.

\subsection{Data analysis}

All statistical analyses were carried out using SPSS. Firstly, a descriptive analysis of the frequency distribution and mean values were conducted. Mean, minimum and maximum values, as well as standard deviation were computed for each standard type and for the different groups of standard setters to prepare the data for further analysis.

Secondly, we carried out analyses of variance (ANOVAs). This approach is particularly appropriate for comparing groups and detecting significant differences between them (Ross and Willson, 2017). We tested for the two independent variables (standard type and standard-setter), respectively, to explore whether standards belonging to different groups differed significantly based on their accountability mechanisms.

Thirdly, the relative importance and weight of each accountability mechanism were elicited through a principal component analysis (PCA) (Vidal et al., 2016) to explore our data further. We first extracted the initial eigenvalues and built a correlation matrix, identifying the principal components that explained the largest variance within our sample. The most frequently used approach for the extraction of pertinent factors is the "root greater than one" criterion (Jolliffe and Cadima, 2016). Originally suggested by Kaiser (1960; cited in Cliff, 1988), this criterion retains only those components whose eigenvalues are greater than one. The reasoning behind this criterion is that an eigenvalue less than one implies that scores on the component have negative reliability (Cliff, 1988).

Subsequently, components fulfilling this criterion were used to calculate rotated component scores for all seven accountability mechanisms with varimax rotation and Kaiser normalization (Table 8). The rotated component matrix, sometimes referred to as the loadings, contains estimates of the correlations between each of the variables and the estimated components. Factor loadings of $>0.5$ are usually considered acceptable; any loadings $<0.4$ are considered trivial (Jolliffe and Cadima, 2016).

\subsection{Limitations}

Our research design also has some limitations. Our analysis was limited to seven design characteristics pertinent for accountability. This does not preclude that other design characteristics may play a role as well. In the same vein, our analysis only allows a comparison of accountability mechanisms amongst the sampled standards. This means that the findings of this study are not generalizable beyond our sample. More work is needed to establish whether the relationships derived from the stock of available case studies and conceptual work also hold up to empirical testing and can be generalized across CSR standards.

\section{Findings}

Table 4 presents a univariate, descriptive analysis of the sample by standard type and standard setter. Principle-based, certification and process standards are well represented with $13(26 \%), 14(28 \%)$ and 18 exemplars (36\%), respectively. As there are fewer widely applied reporting standards than there are other standard types, these are somewhat under- 
SAMPJ

13,1

\section{4}

Table 4.

Descriptive statistics by standard type and standard-setter

represented in the sample with five exemplars (10\%). in addition, the sample reflects the full variety of potential standard setters with 11 exemplars (22\%) issued by businesses, 12 exemplars (24\%) offered by non-profit organizations (NGOs), 14 standards (28\%) advanced by international organizations (IGOs), eight exemplars (16\%) provided by multi-stakeholder initiatives (MSIs) and five (10\%) by partnership initiatives (PIs)

The mean values, ranging from 2.12 to 3.28 , show variation between the levels of intensity of the seven coded design characteristics for different standard types. This is to say that the higher the mean values, the better equipped the standards are to promote accountability. The variation between CSR standards from different standard setters ranges from 2.46 to 3.20. A higher mean value means a higher level of intensity of the respective accountability mechanism. Overall, certification and reporting standards show the highest mean values. Amongst the different types of standard setters, non-profit organizations advanced standards with the highest mean value.

One-way ANOVAs were conducted to explore the variance in accountability mechanisms between different types of standards as well as between standards advanced by different sponsors. We expected that the variance between the four types of standards would be significant. Our analysis (Table 5$)$ confirms this expectation $(F(3.46)=8.998$; $p=$ 0.000 ).

Certification standards $(M=3.28)$ tend to display the highest levels of intensity across all design characteristics. This is to say they are better equipped to ensure compliance compared with the other standard types under investigation. The group of certification standards also includes the case with the highest mean value in the sample $(M=4.43)$, notably the SA 8.000 standard by Social Accountability International. The group of

\begin{tabular}{|c|c|c|c|c|c|}
\hline Standard type & & $\begin{array}{l}\text { Principle-based } \\
\text { standards }\end{array}$ & $\begin{array}{l}\text { Certification } \\
\text { standards }\end{array}$ & $\begin{array}{c}\text { Process } \\
\text { standards }\end{array}$ & Reporting standards \\
\hline$n$ & & 13 & 14 & 18 & 5 \\
\hline$\%$ & & 26 & 28 & 36 & 10 \\
\hline Mean & & 2.12 & 3.28 & 2.60 & 3.20 \\
\hline Minimum & & 1.29 & 1.71 & 1.71 & 2.14 \\
\hline Maximum & & 2.86 & 4.43 & 4.29 & 4.00 \\
\hline $\mathrm{SD}$ & & 0.43584 & 0.72943 & 0.62856 & 0.66701 \\
\hline Standard setter & Business & $\begin{array}{l}\text { Non-profit } \\
\text { organization }\end{array}$ & $\begin{array}{l}\text { International } \\
\text { organization }\end{array}$ & MSI & $\begin{array}{l}\text { Partnership } \\
\text { initiative }\end{array}$ \\
\hline$n$ & 11 & 12 & 14 & 8 & 5 \\
\hline$\%$ & 22 & 24 & 28 & 16 & 10 \\
\hline Mean & 2.64 & 3.20 & 2.54 & 2.46 & 2.72 \\
\hline Minimum & 1.86 & 1.71 & 1.29 & 1.71 & 1.86 \\
\hline Maximum & 4.29 & 4.43 & 4.29 & 3.29 & 3.29 \\
\hline $\mathrm{SD}$ & 0.69800 & 0.80510 & 0.85845 & 0.46436 & 0.54427 \\
\hline
\end{tabular}

Table 5.

Results of ANOVA for standard types

\begin{tabular}{lccccc}
\hline & Sum of squares & df & Mean square & F & Sig. \\
\hline Between groups & 10.383 & 3 & 3.461 & $\mathbf{8 . 9 9 8}$ & $\mathbf{0 . 0 0 0}$ \\
Within groups & 17.692 & 46 & 0.385 & & \\
Total & 28.075 & 49 & & & \\
\hline
\end{tabular}


reporting standards follows a close second $(M=3.18)$. Process standards $(M=2.60)$ and principle-based standards $(M=2.12)$ display relatively lower levels of intensity across all accountability mechanisms. Principle-based standards are the group with the lowest minimum (1.29, ILO's Declaration on Fundamental Principles and Rights at Work) and maximum values (2.86, Gender Equality Principles by GEP Initiative), indicating an overall performance that lags behind the other types of CSR standards under investigation.

We were also interested in exploring whether CSR standards vary according to the type of standard setter, as suggested by the literature. Accordingly, CSR standards by independent standard-setters such as non-profit organizations were expected to display higher levels of intensity of the investigated accountability mechanisms. While the descriptive statistics showed that NGOs produce standards with higher mean values than other standard setters (Table 6), this expectation was not confirmed. The variance between standards from different standard setters was found not to be significant $(F(4.45)=1.779$; $p=0.150)$.

Finally, the literature also suggests that CSR standards vary in terms of their specific combination of accountability mechanisms, irrespective of standard type or sponsor. We conducted a PCA to explore which factors contributed most strongly to the variance in accountability mechanisms between CSR standards. Table 7 presents the initial eigenvalues of the correlation matrix. Three reliable components with eigenvalues greater than 1 can be identified, which explain $63.06 \%$ of the total variance within the sample.

The rotated component scores (Table 8) reveal that "standardized evaluation criteria", "verification" and "certification" contribute to the factor load of Component 1. "Metrics" and "standardized issues" contribute to Component 2. "Guidance on effective implementation" is the primary contributor to Component 3 . All other values were below the threshold $(<0.5)$ and are not displayed for the sake of clarity. Benchmarking did not significantly contribute to any of the components and can, therefore, be considered negligible in explaining the variance between CSR standards.

\begin{tabular}{lccccc}
\hline & Sum of squares & df & Mean square & F & Sig. \\
\hline Between groups & 3.839 & 4 & 0.960 & $\mathbf{1 . 7 7 9}$ & $\mathbf{0 . 1 5 0}$ \\
Within groups & 24.277 & 45 & 0.539 & & \\
Total & 28.115 & 49 & &
\end{tabular}

Accountability by design

\begin{tabular}{lccrr}
\hline Component & Total & $\begin{array}{c}\text { Initial eigenvalues } \\
\text { \% of variance }\end{array}$ & Cumulative\% & \\
\cline { 1 - 2 } $\mathbf{1}$ & $\mathbf{2 . 0 9 5}$ & & & \\
$\mathbf{2}$ & $\mathbf{1 . 3 1 1}$ & 29.93 & 29.93 & Table 7. \\
$\mathbf{3}$ & $\mathbf{1 . 0 0 8}$ & 18.73 & 63.66 & Total variance \\
4 & 0.948 & 14.40 & 76.60 & explained, initial \\
5 & 0.742 & 13.55 & 87.20 & eigenvalues \\
6 & 0.567 & 8.10 & 95.31 & extracted through \\
7 & 0.328 & 4.69 & 100.00 & PCA \\
\hline
\end{tabular}


SAMPJ

13,1

16

Component 1 explains $29.93 \%$ of the variance between CSR standards. The accountability mechanisms loading onto this component all contribute to ensuring that the degree of compliance and effective standard implementation is objectively verifiable, can be assessed in a standardized manner and is comparable across adopters. We, therefore, name this component comparability (Table 9). CSR standards that have been found to display a particularly high degree of comparability include the GLOBAL G.A.P. standards, a global quality and sustainability certification system for the agricultural sector (normalized PCA score of 1.000); the FLO Fairtrade standards by Fairtrade Labelling Organizations International (normalized PCA score of 0.878); and the ISO 14 046 environmental management standard for water footprinting (normalized PCA score of 0.866).

Component 2 explains $18.73 \%$ of the variance between CSR standards. The design characteristics contributing to this component refer to the degree to which the sustainability issues addressed by a standard are well specified and the outcomes related to these sustainability issues can be quantitatively measured. We, therefore, use the term measurability (Table 9) to describe this component. CSR standards that perform particularly well for measurability include the B Impact Assessment, a set of sustainability standards for firms that systematically strive to generate social and/or environmental benefits in addition to economic returns (normalized PCA score of 1.000); the greenhouse gas (GHG) Protocol's Corporate Standard for assessing GHG emissions (normalized PCA score of 0.974); as well as the Oxfam Poverty Footprint, a standard for assessing corporate impacts on poverty (normalized PCA score of 0.900 ).

Component 3 explains $14.4 \%$ of the variance between the investigated CSR standards. Only one factor, notably "guidance on effective implementation", substantially loads onto this component. Guidance on effective implementation is geared towards building capacity amongst adopters for achieving compliance with the spirit and the word of CSR standards. We, therefore, name this component implementability (Table 9). Standards that obtained particularly high scores for implementability include the BSCI Code of Conduct by the Business Social Compliance Initiative (normalized PCA score of 1.000); the Natural Step by TNS International (normalized PCA score of 0.840) and the Higg Index, a standard for social and environmental performance in the textile sector developed by the Sustainable Apparel Coalition (normalized PCA score of 0.801).

When comparing the normalized PCA scores across the individual components, we find that $24(48 \%)$ of the sampled CSR standards do perform well with a score of 0.8 or higher against at least one component. However, only $2(4 \%)$ of the sampled standards obtain a score of 0.8 or higher for two components. None of the sampled standards receive a high score of 0.8 or higher for all three components.

\begin{tabular}{llcc}
\hline & \multicolumn{3}{c}{ Rotated component matrix } \\
\hline & 1 & 2 & 3 \\
Guidance on effective implementation & & 0.748 & \\
Metrics & & $\mathbf{0 . 8 1 2}$ & \\
Standardized issues & $\mathbf{0 . 6 2 8}$ & & \\
Standardized evaluation criteria & $\mathbf{0 . 8 4 5}$ & & \\
Verification & $\mathbf{0 . 8 5 1}$ & & \\
Benchmarking & & & \\
Certification & &
\end{tabular}

\section{Table 8.}

Rotated component matrix extracted through PCA, rotation converged in 5 iterations (1) 


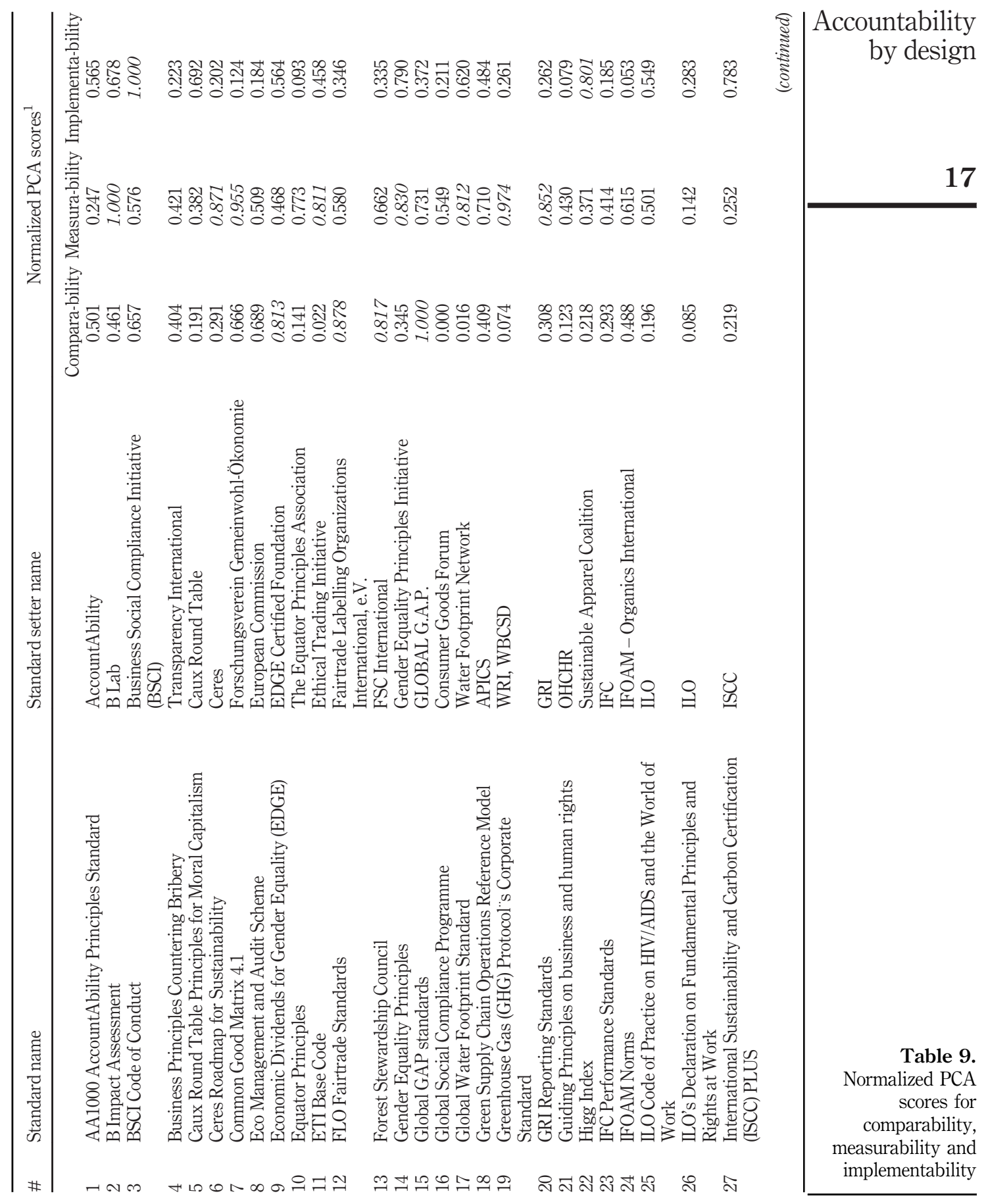




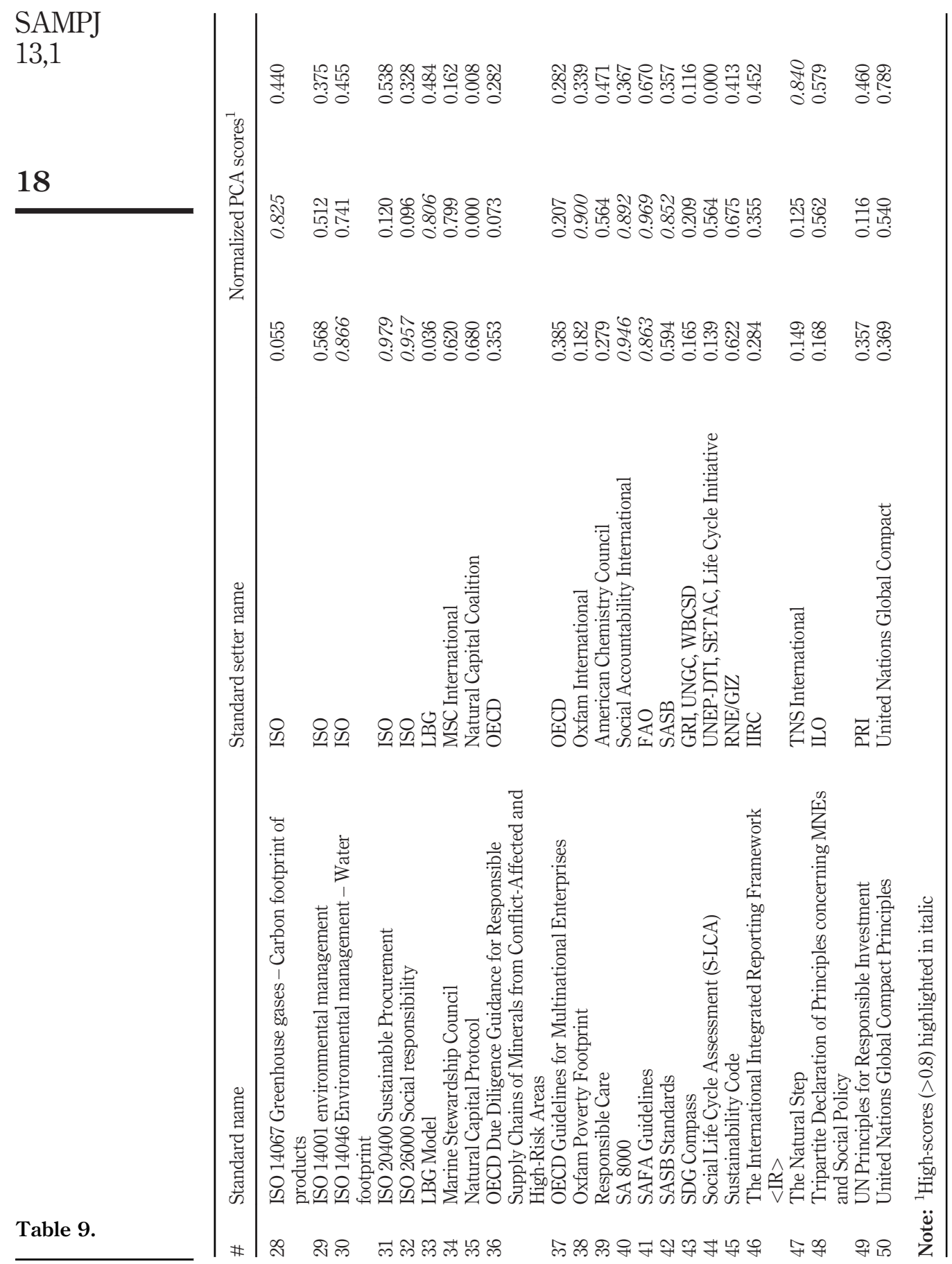




\section{Discussion and conclusions}

Prior research on accountability in the context of CSR standards has mainly focused on the behaviour of firms who adopt them (Bromley and Powell, 2012; Bromley et al., 2012;

Windolph et al., 2014). In contrast, this study explores the accountability mechanisms embedded in the design of CSR standards as antecedents of (non-) compliance within firms (Auld and Gulbrandsen, 2010; Behnam and MacLean, 2011; May, 2007). Our study broadens the scope of analysis to a sample of 50 CSR standards that cover the spectrum of standard types and standard-setting initiatives currently available (Fransen et al., 2019). We ask: to what extent are CSR standards designed for accountability?

Our findings confirm that principle-based, certification, process and reporting standards vary significantly in terms of their design characteristics and related accountability mechanisms. This is in line with classifications that have been advanced previously in conceptual and case-study-based contributions (Behnam and MacLean, 2011; Gilbert et al., 2011). The intensity of accountability mechanisms contained within CSR standards varies according to the type of standard. Certification standards as a group displayed a significantly higher intensity in accountability-related design characteristics than any other group and comprise the standard with the single highest mean value in the sample, SA 8.000 (Sartor et al., 2016). Principle-based standards as a group displayed the lowest intensity across all design characteristics, with the lowest mean value for the ILO Declaration on Fundamental Principles and Rights at Work (Islam and McPhail, 2011).

In light of this finding, the question arises: are certification standards generally preferable over principle-based standards when it comes to accountability? As both the highest and lowest intensity values are held by CSR standards focusing on labour issues, an interpretation based on a direct comparison between these two exemplars is possible. The certification standard SA 8000 was the first auditable CSR standard focusing on labour, health and safety issues globally (Sartor et al., 2016). According to Behnam and MacLean (2011), it stands out amongst CSR standards because it provides specific implementation guidance, presents sanctioning mechanisms for non-compliance, requires evidence of performance and exhibits high costs of adoption (Sartor et al., 2016). In contrast, the principle-based standard ILO Fundamental Principles is easy to adopt because it does not entail costly assessments or certification processes. This suggests that, between the two standards, SA 8000 is the one that is designed for accountability.

Yet, it suffers from what Rasche (2010) calls the limit of standardization in the CSR space:

[. . .][standards] are never sufficient to take into account the contextuality and singularity that genuine corporate responsibility calls for. At best, standards can give corporations an idea about where reflections need to start and which issues are at stake. At worst, standards promote a "going-by-the-book" and "tick-the-boxes" attitude towards corporate responsibility, which has a marginal, if any, effect on real-life practices.

Considered from this perspective, the ILO Fundamental Principles might well be better suited to encourage reflection on labour issues and practices than SA 8000 (Islam and McPhail, 2011). For future work, this implies that when it comes to "hard" facts on accountability mechanisms, the standard type is clearly an important variable to consider. However, this does not preclude that CSR standards with a "softer" stance on accountability mechanisms have merits as well, especially when it comes to sustainability issues that are contested or newly emerging.

Secondly, we analysed whether the type of standard setter has some bearing on the extent to which accountability mechanisms are embedded into the design of the CSR standards (Carmin et al., 2003). However, this proposition was not supported by the data. Rather, many of the CSR standards displaying a high intensity across the coded 
SAMPJ

13,1

accountability mechanisms were issued by business sponsors. This is particularly interesting, as business initiatives are frequently under suspicion of putting business interests first and building communication smokescreens, rather than investing in ensuring substantive accountability (Bromley and Powell, 2012; Milne and Gray, 2013; Vigneau et al., 2015). Our analysis paints a rather different picture.

Overall, there was no significant difference in terms of accountability mechanisms between standards offered by the business, non-profit organizations, international organizations and multi-stakeholder or partnership initiatives. However, some scholars argue that an ongoing trend towards an increasing multiplicity of standards in the same sectors and issue areas have led to competition amongst standard setters and the ability of incumbents to choose the standard that requires the least change in practices (Fransen et al., 2019; Reinecke et al., 2012; Chkanikova and Sroufe, 2020). This suggests that researchers suspecting a "race to the bottom" in CSR standards should not merely look at the standardsetting organization or initiative. Rather, the number of available standards in a given sectoral or supply chain context might be a better starting point.

Thirdly, there are specific combinations of accountability mechanisms that matter for explaining the variance between CSR standards. We identified three principal components, which we named "comparability", i.e. the degree to which a standard enables comparisons across time and across adopters; "measurability", i.e. the degree to which evaluation criteria and performance metrics are well-specified and quantifiable; and "implementability", i.e. the degree to which guidance on effective implementation is available to support adopters in achieving compliance.

The GLOBAL G.A.P. standards performed best on comparability. This standard is implemented largely in international agricultural value chains with uneven terms of trade between smallholders in the global south, exporters and large retailers in the global north (Otieno et al., 2017). Because of the sectoral context, the standard is mainly intended to diffuse sustainable and socially responsible good practices. These are standardized and substantive guidance on implementation is provided. This fosters close collaboration along supply chains and, thus, has implications beyond individual firms that adopt the standards. Operating in a similar context, the FLO Fairtrade Standards and the FAO's SAFA Guidelines also perform exceptionally well on comparability.

It is notable that reporting standards, which explicitly aim for comparability in CSR disclosures, are not amongst the top scorers. One possible interpretation of this finding is that the ambition to achieve universal applicability across sectors makes it difficult to clearly define, measure and evaluate sustainability outcomes so that they are applicable across sector contexts, yet still relevant and useful for individual firms. This suggests that comparability might be easier to achieve within a specified sector context, where the salient sustainability issues are well defined. In this context, it is interesting to note that sponsors of reporting standards do increasingly account for sectoral specificities in their standards (e.g. the GRI Standards or the SASB Standards).

Measurability was most pronounced in the B Corp Certification standards. The standards are integrated into a comprehensive and regularly revised B Impact Assessment Tool, which is geared towards enabling participating firms to measure and improve their sustainability impacts (Villela et al., 2019). In the same vein, other standards performing well on measurability also stress their reliance on science-based targets and well-defined indicators and robust quantitative assessments, for instance, the GHG Protocol (Hickmann, 2017). This suggests that for high-scoring CSR standards in this area a focus on measurability is an actual design focus adopted by standard-setting initiatives when developing the standards, possibly even at the expense of other accountability mechanisms. 
The Natural Step and the Higg Index both achieved high scores for implementability. They contain elaborate guidance, consultancy and capacity building services as well as training opportunities for firms wishing to implement them. As such, these standards place emphasis on ensuring that adopting firms are well-equipped to understand the issues at stake, to translate them into their corporate context and to implement them in daily practice. At the same time, other accountability mechanisms display relatively low-intensity levels in these standards. As Rasche (2009) notes: sometimes a standard "is not designed as an enforcement tool for global rules, but reflects a learning network that fosters their implementation and dissemination" (Rasche, 2009, p. 201). This might be the case for standards that favour implementability.

For practice, our findings suggest that there are different design strategies that standardsetting organizations and initiatives can pursue. The sampled standards generally do not perform well on more than one component. It might be necessary to choose either comparability, measurability or implementability as the focal goal in standard design to achieve excellence (in our study this means a normalized PCA score of 0.8 or higher) [1]. This chimes with Wijen (2014), who argues that there may be irreconcilable trade-offs between these different factors.

However, there is also one example that displays a more balanced performance. The BSCI Code of Conduct, a process standard focusing on labour issues along the supply chains of retail, brand and importing firms, achieves medium to high scores $>0.5$ for all three components. The standard combines a number of different accountability mechanisms such as external verification, network collaboration and technical assistance for standard implementation. In addition, it links up with other related standards in the field (e.g. SA 8000) with the ultimate objective to create consistency and harmonization in firm practices (Terwindt and Armstrong, 2019). This goes to show it is possible, albeit rare, for standardsetting initiatives to adopt a design strategy that successfully addresses all three components.

For research, our study affirms the need to continue the investigation and comparison of the design characteristics of larger groups of standards from different perspectives (Wiengarten et al., 2016; Zinenko et al., 2015). No "best CSR standard" can be determined based on our analysis; we posit that the findings of our analysis should be carefully interpreted with consideration for the specific purpose for which each standard was designed. Nevertheless, our findings suggest that future studies would do well to consider standard design more explicitly when examining the performance of CSR standards, not only as regard accountability but also in regard to other important performance criteria such as legitimacy (O'Dwyer et al., 2011; Richards et al., 2017), contributions to organizational transformation (Martinuzzi and Krumay, 2013) or the achievement of substantial contributions to sustainable development (Schönherr et al., 2017; Milne and Gray, 2013), to list but a few. This study should be considered the first step towards such a broader consideration of CSR standards. It provides a first comparative exploration of a substantive set of CSR standards and the extent to which accountability mechanisms are incorporated into their design.

\section{Note}

1. The two notable exceptions from this are the FAO's SAFA Guidelines and the SA 8000 standard by Social Accountability International. Their distinctive features have already been discussed elsewhere in this manuscript. 
SAMPJ

13,1

\section{References}

Ählström, J. (2010), "Corporate response to CSO criticism: decoupling the corporate responsibility discourse from business practice", Corporate Social Responsibility and Environmental Management, Vol. 17 No. 2, pp. 70-80.

Akkucuk, U. (Ed.) (2016), Ethics and Sustainability in Global Supply Chain Management, IGI Global.

Albareda, L. and Waddock, S. (2017), "Networked CSR governance”, Business and Society, Vol. 40, p. 000765031562420.

Alexius, S. and Furusten, S. (2019), "Hybrid challenges in times of changing institutional conditions: the rise and fall of the natural step as a multivocal bridge builder", Managing Hybrid Organizations, Palgrave Macmillan, Cham, pp. 267-285.

Arevalo, J.A., Aravind, D., Ayuso, S. and Roca, M. (2013), "The global compact: an analysis of the motivations of adoption in the Spanish context", Business Ethics: A European Review, Vol. 22 No. 1, pp. 1-15.

Auld, G. and Gulbrandsen, L.H. (2010), "Transparency in nonstate certification: consequences for accountability and legitimacy", Global Environmental Politics, Vol. 10 No. 3, pp. 97-119.

de Bakker, F.G., Rasche, A. and Ponte, S. (2019), "Multi-stakeholder initiatives on sustainability: a crossdisciplinary review and research agenda for business ethics", Business Ethics Quarterly, Vol. 29 No. 3, pp. 343-383.

Banerjee, S.B. (2011), "Embedding sustainability across the organization: a critical perspective", Academy of Management Learning and Education, Vol. 10 No. 4, pp. 719-731.

Bassen, A., Rentrop, A. and Zwick, Y. (2011), "Deutscher Nachhaltigkeitskodex (DNK) - Konzept, Inhalte und Entwicklungsschritte", Zeitschrift fur Umweltpolitik und Umweltrecht, Vol. 34 No. 3, p. 359 .

Bebbington, J. (2009), "Measuring sustainable development performance. Possibilities and issues", Accounting Forum, Vol. 33 No. 3, pp. 189-193.

Behnam, M. and MacLean, T.L. (2011), "Where is the accountability in international accountability standards? A decoupling perspective", Business Ethics Quarterly, Vol. 21 No. 1, pp. 45-72.

Benoit-Norris, C., Vickery-Niederman, G., Valdivia, S., Franze, J., Traverso, M., Ciroth, A. and Mazijn, B. (2011), "Introducing the UNEP/SETAC methodological sheets for subcategories of social LCA". The International Journal of Life Cycle Assessment, Vol. 16 No. 7, pp. 682-690.

Bies, R. (2014), "At the crossroads of trust and distrust. Skepticism and ambivalence toward business", In Public Trust in Business, Cambridge University Press, Cambridge, pp. 86-115.

Blair, M.M. (1995), Ownership and Control: Rethinking Corporate Governance for the Twenty-First Century, Brookings Inst, Washington, DC.

Blankenbach, J. (2016), "Voluntary sustainability standards and the role of the government. Perspectives from emerging market economies and Europe", available at: http://www.die-gdi.de/uploads/ tx_veranstaltung/20161021_Voluntary_Sustainability_Standards_UNFSS_conference_report.pdf (accessed 6 December 2017).

Boiral, O. and Gendron, Y. (2011), "Sustainable development and certification practices. Lessons learned and prospects", Business Strategy and the Environment, Vol. 20 No. 5, pp. 331-347.

Brammer, S., Jackson, G. and Matten, D. (2012), "Corporate social responsibility and institutional theory: new perspectives on private governance", Socio-Economic Review, Vol. 10 No. 1, pp. 3-28.

Bromley, P. and Powell, W.W. (2012), "From smoke and mirrors to walking the Talk. Decoupling in the Contemporary World", Academy of Management Annals, Vol. 6 No. 1, pp. 483-530.

Bromley, P., Hwang, H. and Powell, W.W. (2012), "Decoupling revisited. Common pressures, divergent strategies in the US nonprofit sector", Management, Vol. 15 No. 5, p. 469. 
Brunsson, N., Rasche, A. and Seidl, D. (2012), "The dynamics of standardization. Three perspectives on standards in organization studies", Organization Studies, Vol. 33 Nos 5/6, pp. 613-632.

Burritt, R.L. and Schaltegger, S. (2010), "Sustainability accounting and reporting. Fad or trend?", Accounting, Auditing and Accountability Journal, Vol. 23 No. 7, pp. 829-846.

Busco, C., Consolandi, C., Eccles, R. G. and Sofra, E. (2020), "A preliminary analysis of SASB reporting: disclosure topics, financial relevance, and the financial intensity of ESG materiality", Journal of Applied Corporate Finance, Vol. 32 No. 2, pp. 117-125.

Carmin, J., Darnall, N. and Mil-Homens, J. (2003), "Stakeholder involvement in the design of US voluntary environmental programs: does sponsorship matter?”, Policy Studies Journal, Vol. 31 No. 4, pp. 527-543.

Carroll, A.B. (2013), "Caux round table principles”, in Idowu, S.O., Capaldi, N., Zu, L. and Gupta, A.D. (Eds), Encyclopedia of Corporate Social Responsibility: With 227 Figures and 119 Tables, Springer Reference, Springer, Berlin, Heidelberg, pp. 327-332.

Chatzidakis, A. and Maclaran, P. (2020), "Gendering consumer ethics", International Journal of Consumer Studies, Vol. 44 No. 4, pp. 316-327.

Chiputwa, B., Spielman, D.J. and Qaim, M. (2015), "Food standards, certification, and poverty among coffee farmers in Uganda”, World Development, Vol. 66, pp. 400-412.

Chkanikova, O. and Sroufe, R. (2020), "Third-party sustainability certifications in food retailing: certification design from a sustainable supply chain management perspective", Journal of Cleaner Production, p. 124344.

Christensen, H., Hail, L. and Leuz, C. (2019), Adoption of CSR and Sustainability Reporting Standards: Economic Analysis and Review, Cambridge, MA.

Christmann, P. and Taylor, G. (2002), "Globalization and the environment: strategies for international voluntary environmental initiatives", Academy of Management Perspectives, Vol. 16 No. 3, pp. 121-135.

Christmann, P. and Taylor, G. (2006), "Firm self-regulation through international certifiable standards: determinants of symbolic versus substantive implementation", Journal of International Business Studies, Vol. 37 No. 6, pp. 863-878.

Cliff, N. (1988), “The eigenvalues-greater-than-one rule and the reliability of components”, Psychological Bulletin, Vol. 103 No. 2, pp. 276-279.

Conzelmann, T. (2012), "A procedural approach to the design of voluntary clubs: negotiating the responsible care global charter”, Socio-Economic Review, Vol. 10 No. 1, pp. 193-214.

Curran, L. and Eckhardt, J. (2020), "Mobilizing against the antiglobalization backlash: an integrated framework for corporate nonmarket strategy", Business and Politics, Vol. 22 No. 4, pp. 612-638.

Dalal-Clayton, D.B. and Bass, S. (2011), Sustainable Development Strategies: A Resource Book, Earthscan, London, Sterling, VA.

Delmas, M.A. and Montes-Sancho, I.M.J. (2011), “An institutional perspective on the diffusion of international management system standards: the case of the environmental management standard ISO 14001”, Business Ethics Quarterly, Vol. 21 No. 1, pp. 103-132.

Derkx, B. and Glasbergen, P. (2014), "Elaborating global private meta-governance: an inventory in the realm of voluntary sustainability standards", Global Environmental Change, Vol. 27, pp. 41-50.

Dietz, T., Grabs, J. and Chong, A.E. (2019), "Mainstreamed voluntary sustainability standards and their effectiveness: evidence from the honduran coffee sector", Regulation and Governance, Vol. 15 No. 2, pp. 333-355.

Dyllick, T. and Muff, K. (2016), "Clarifying the meaning of sustainable business", Organization and Environment, Vol. 29 No. 2, pp. 156-174. 
SAMPJ

13,1

Edens, B., Hoekstra, R., Zult, D., Lemmers, O., Wilting, H. and Wu, R. (2015), "A method to create carbon footprint estimates consistent with national accounts", Economic Systems Research, Vol. 27 No. 4, pp. 440-457.

Esteves, A.M., Franks, D. and Vanclay, F. (2012), "Social impact assessment: the state of the art", Impact Assessment and Project Appraisal, Vol. 30 No. 1, pp. 34-42.

Feige, A. (2016), ISCC-Vorreiter bei der Zertifizierung von Nachhaltigkeit und Treibhausgasemissionen. In Zertifizierung als Erfolgsfaktor, Springer Gabler, Wiesbaden, pp. 189-204.

Felber, C. (2019), This is Not Economy: Aufruf zur Revolution der Wirtschaftswissenschaft, Paul Zsolnay Verlag.

Feng, N.C., Neely, D.G. and Slatten, L.A.D. (2016), "Accountability standards for nonprofit organizations: do organizations benefit from certification programs?”, International Journal of Public Administration, Vol. 39 No. 6, pp. 470-479.

Fonseca, A., McAllister, M.L. and Fitzpatrick, P. (2014), "Sustainability reporting among mining corporations: a constructive critique of the GRI approach", Journal of Cleaner Production, Vol. 84, pp. 70-83.

Fransen, L.W. and Kolk, A. (2007), "Global rule-setting for business: a critical analysis of multiStakeholder standards”, Organization, Vol. 14 No. 5, pp. 667-684.

Fransen, L., Kolk, A. and Rivera-Santos, M. (2019), "The multiplicity of international corporate social responsibility standards", Multinational Business Review, Vol. 27 No. 4, pp. 397-426.

Fraser, I.J., Schwarzkopf, J. and Müller, M. (2020), "Exploring supplier sustainability audit standards: Potential for and barriers to standardization”, Sustainability, Vol. 12 No. 19, p. 8223.

Freyer, B. and Bingen, J. (2014), "Organic and non-organic farming: is convergence possible?", Alternative Agrifood Movements: Patterns of Convergence and Divergence, Emerald Group Publishing.

Gardels, N. and Berggruen, N. (2017), "Salvaging globalization”, New Perspectives Quarterly, Vol. 34 No. 1, pp. 67-79.

Gilbert, D.U., Rasche, A. and Waddock, S. (2011), “Accountability in a global economy: the emergence of international accountability standards", Business Ethics Quarterly, Vol. 21 No. 1, pp. 23-44.

Grafton, J., Malina, M.A., Nørreklit, H.S. and Selto, F.H. (2011), "Lessons learned: advantages and disadvantages of mixed method research", Qualitative Research in Accounting and Management, Vol. 8 No. 1, pp. 59-71.

Grimm, J., Schormair, M. and Gilbert, D.U. (2020), "Co-Constructing decoupling and recoupling: a process perspective on the IAS DETOX”, Academy of Management Proceedings, Vol. 2020 No. 1, pp. 17262.

Gond, J.P. and Piani, V. (2013), "Enabling institutional investors' collective action: the role of the principles for responsible investment initiative”, Business \& Society, Vol. 52 No. 1, pp. 64-104.

Haack, P. and Schoeneborn, D. (2015), "Is decoupling becoming decoupled from institutional theory? A commentary on Wijen", Academy of Management Review, Vol. 40 No. 2, pp. 307-310.

Hachez, N. and Wouters, J. (2011), "A glimpse at the democratic legitimacy of private standards: assessing the public accountability of Global G.A.P”, Journal of International Economic Law, Vol. 14 No. 3, pp. 677-710.

Hahn, R. (2013), "ISO 26000 and the standardization of strategic management processes for sustainability and corporate social responsibility", Business Strategy and the Environment, Vol. 22 No. 7, pp. 442-455.

Hahn, R. and Weidtmann, C. (2016), "Transnational governance, deliberative democracy, and the legitimacy of ISO 26000", Business and Society, Vol. 55 No. 1, pp. 90-129. 
Heras-Saizarbitoria, I. and Boiral, O. (2013), "ISO 9001 and ISO 14001. Towards a research agenda on management system standards*”, International Journal of Management Reviews, Vol. 15 No. 1, pp. 47-65.

Hickmann, T. (2017), "Voluntary global business initiatives and the international climate negotiations: a case study of the greenhouse gas protocol", Journal of Cleaner Production, Vol. 169, pp. 94-104.

Hoekstra, A.Y., Chapagain, A.K., Mekonnen, M.M. and Aldaya, M.M. (2011), The Water Footprint Assessment Manual: Setting the Global Standard, Routledge.

Islam, M.A. and McPhail, K. (2011), "Regulating for corporate human rights abuses: the emergence of corporate reporting on the ILO's human rights standards within the global garment manufacturing and retail industry", Critical Perspectives on Accounting, Vol. 22 No. 8, pp. $790-810$.

Islam, M.A. and van Staden, C.J. (2018), "Social movement NGOs and the comprehensiveness of conflict mineral disclosures: evidence from global companies", Accounting, Organizations and Society, Vol. 65, pp. 1-19.

Jolliffe, I.T. and Cadima, J. (2016), "Principal component analysis: a review and recent developments", Philosophical Transactions. Series A, Mathematical, Physical, and Engineering Sciences, Vol. 374 No. 2065, p. 20150202.

Kaiser, H.F. (1960), "The application of electronic computers to factor analysis", Educational and Psychological Measurement, Vol. 20, pp. 141-151.

Kannenberg, L. and Schreck, P. (2019), "Integrated reporting: boon or bane? A review of empirical research on its determinants and implications", Journal of Business Economics, Vol. 89 No. 5, pp. 515-567.

Kashmanian, R.M., Wells, R.P. and Keenan, C. (2011), "Corporate environmental sustainability strategy: Key elements", Journal of Corporate Citizenship, No. 44, pp. 107-130.

Komives, K. and Jackson, A. (2014), "Introduction to voluntary sustainability standard systems", in Schmitz-Hoffmann, C., Schmidt, M., Hansmann, B. and Palekhov, D. (Eds), Voluntary Standard Systems: A Contribution to Sustainable Development, Natural Resource Management in Transition, Springer Berlin Heidelberg, Berlin, Heidelberg, s.l., pp. 3-19.

Leipziger, D. (2003), The Corporate Responsibility Code Book, Greenleaf, Sheffield.

Leipziger, D. (2017), The Corporate Responsibility Code Book, Rev, 2nd ed., Greenleaf Pub, Sheffield.

Lenssen, G. and Blowfield, M. (2012), "Business and development", Corporate Governance: The International Journal of Business in Society, Vol. 12 No. 4, pp. 414-426.

Liberti, L. (2012), "OECD 50th anniversary: the updated OECD guidelines for multinational enterprises and the new OECD recommendation on due diligence guidance for conflict-free mineral supply chains", Business Law International, Vol. 13 No. 35.

Martinuzzi, A. and Krumay, B. (2013), "The good, the bad, and the successful - how corporate social responsibility leads to competitive advantage and organizational transformation", Journal of Change Management, Vol. 13 No. 4, pp. 424-443.

Martinuzzi, A. and Schönherr, N. (2019), "Introduction: the and the future of", in Martinuzzi, A. (Ed.), Business and the Sustainable Development Goals: Measuring and Managing Corporate Impacts, Palgrave Pivot, Springer International Publishing, Cham, pp. 1-17.

Marx, A. (2013), "Varieties of legitimacy: a configurational institutional design analysis of eco-labels", innovation: the European”, Journal of Social Science Research, Vol. 26 No. 3, pp. 268-287.

May, P.J. (2007), "Regulatory regimes and accountability", Regulation and Governance, Vol. 1 No. 1, pp. 8-26.

Michelon, G., Pilonato, S., Ricceri, F. and Roberts, R.W. (2016), "Behind camouflaging: traditional and innovative theoretical perspectives in social and environmental accounting research", Sustainability Accounting, Management and Policy Journal, Vol. 7 No. 1, pp. 2-25. 
SAMPJ

13,1

Migliore, M., Talamo, C. and Paganin, G. (2020), "Circular economy and sustainable procurement: the role of the attestation of conformity", Strategies for Circular Economy and Cross-sectoral Exchanges for Sustainable Building Products, Springer, Cham, pp. 159-173.

Milne, M.J. and Gray, R. (2013), "W(h)ither ecology? The triple bottom line, the global reporting initiative, and corporate sustainability reporting”, Journal of Business Ethics, Vol. 118 No. 1, pp. 13-29.

Moog, S., Spicer, A. and Böhm, S. (2015), "The politics of multi-stakeholder initiatives: the crisis of the Forest Stewardship Council", Journal of Business Ethics, Vol. 128 No. 3, pp. 469-493.

Muff, K., Kapalka, A. and Dyllick, T. (2017), "The gap frame-translating the SDGs into relevant national grand challenges for strategic business opportunities", The International Journal of Management Education, Vol. 15 No. 2, pp. 363-383.

O'Dwyer, B., Owen, D. and Unerman, J. (2011), "Seeking legitimacy for new assurance forms: the case of assurance on sustainability reporting", Accounting, Organizations and Society, Vol. 36 No. 1, pp. 31-52.

Oldenziel, J. and Wilde-Ramsing, J. (2010), "10 Years on: assessing the contribution of the OECD guidelines for multinational enterprises to responsible business conduct", Available at SSRN 1641036.

Otieno, P., Ogutu, C., Mburu, J. and Nyikal, R. (2017), "Effect of Global-GAP policy on climate change perceptions of smallholder French beans farmers in Central and Eastern regions, Kenya", Climate, Vol. 5 No. 2, pp. 27.

Overdevest, C. (2010), "Comparing Forest certification schemes: the case of ratcheting standards in the Forest sector”, Socio-Economic Review, Vol. 8 No. 1, pp. 47-76.

Perego, P. and Kolk, A. (2012), "Multinationals' accountability on sustainability. The evolution of third-party assurance of sustainability reports”, Journal of Business Ethics, Vol. 110 No. 2, pp. 173-190.

Peterson, E., Nehring, J. and Sakai, R. (2020), S\&P 500 Flash Report 2020: Trends on the Sustainability Reporting Practices of S\&P 500 Index Companies, New York, NY, available at: http://www.gainstitute.com/fileadmin/ga_institute/images/FlashReports/2020/G_A-Flash-Report-2020.pdf

Pivot Goals (2017), "Pivot goals. The sustainability goals of the world's largest and leading companies", available at: http://www.pivotgoals.com/

Ponte, S. (2012), "The marine stewardship council (MSC) and the making of a market for 'sustainable fish", Journal of Agrarian Change, Vol. 12 Nos 2/3, pp. 300-315.

Popa, D.I. and Dabija, D.C. (2019), "ISO 26000: a brief literature review", in Idowu, S.O., Sitnikov, C. and Moratis, L. (Eds), ISO 26000 - A Standardized View on Corporate Social Responsibility: Practices, Cases and Controversies, CSR, Sustainability, Ethics and Governance, Springer International Publishing, Cham, pp. 81-92.

Pope, S. and Lim, A. (2020), "The governance divide in global corporate responsibility: the global structuration of reporting and certification frameworks, 1998-2017", Organization Studies, Vol. 41 No. 6, pp. 821-854.

Potts, J., Lynch, M., Wilkings, A., Huppé, G., Cunningham, M. and Voora, V. (2014), "The state of sustainability initiatives review 2014: Standards and the green economy", available at: http:// www.iisd.org/sites/default/files/pdf/2014/ssi_2014.pdf (accessed 30 November 2017).

Prakash, A. and Potoski, M. (2007), "Collective action through voluntary environmental programs. A club theory perspective", Policy Studies Journal, Vol. 35 No. 4, pp. 773-792.

Radhakrishnan, S. (2015), "The sustainable apparel coalition and the higg index”, Roadmap to Sustainable Textiles and Clothing, Springer, Singapore, pp. 23-57.

Rasche, A. (2009), "Toward a model to compare and analyze accountability standards - the case of the UN global compact", Corporate Social Responsibility and Environmental Management, Vol. 16 No. 4, pp. 192-205. 
Rasche, A. (2010), "The limits of corporate responsibility standards", Business Ethics: A European Review, Vol. 19 No. 3, pp. 280-291.

Rasche, A. (2014), "Voluntary standards as enablers and impediments to sustainable consumption", SSRN Electronic Journal.

Rasche, A. and Seidl, D. (2019), "Management ideas as standards", in Sturdy, A., Heusinkveld, S. and Reay, T. (Eds), The Oxford Handbook of Management Ideas, Oxford Handbooks, 1st ed., Oxford University Press, pp. 336-353.

Reinecke, J., Manning, S. and von Hagen, O. (2012), "The emergence of a standards market. Multiplicity of sustainability standards in the global coffee industry", Organization Studies, Vol. 33 Nos 5/6, pp. 791-814.

Reinert, K.A., Reinert, O.T. and Debebe, G. (2016), "The new OECD guidelines for multinational enterprises: better but not enough", Development in Practice, Vol. 26 No. 6, pp. 816-823.

Richards, M., Zellweger, T. and Gond, J.P. (2017), "Maintaining moral legitimacy through worlds and words: an explanation of firms' investment in sustainability certification", Journal of Management Studies, Vol. 54 No. 5, pp. 676-710.

de Ridder, W., Turnpenny, J., Nilsson, M. and Raggamby, A. von (2007), "A framework for tool selection and use in integrated assessment for sustainable development", Journal of Environmental Assessment Policy and Management, Vol. 09 No. 04, pp. 423-441.

Ross, A. and Willson, V.L. (2017), "One-Way Anova”, in Ross, A. and Willson, V.L. (Eds), Basic and Advanced Statistical Tests, SensePublishers, Rotterdam, pp. 21-24.

Ruggie, J. (2011), "Report of the special representative of the secretary-general on the issue of human rights and transnational corporations and other business enterprises: guiding principles on business and human rights: implementing the united nations 'protect, respect and remedy' framework", Netherlands Quarterly of Human Rights, Vol. 29 No. 2, pp. 224-253.

Saldaña, J. (2016), The Coding Manual for Qualitative Researchers, 3. ed., SAGE, Los Angeles, Calif., London, New Delhi, Singapore, Washington, DC.

Sartor, M., Orzes, G., Di Mauro, C., Ebrahimpour, M. and Nassimbeni, G. (2016), “The SA8000 social certification standard: literature review and theory-based research agenda", International Journal of Production Economics, Vol. 175, pp. 164-181.

Schader, C., Grenz, J., Meier, M.S. and Stolze, M. (2014), "Scope and precision of sustainability assessment approaches to food systems", Ecology and Society, Vol. 19 No. 3.

Schepers, D.H. (2011), "The Equator Principles: a promise in progress?", Corporate Governance: The International Journal of Business in Society.

Scherer, A.G. and Palazzo, G. (2011), "The new political role of business in a globalized world: a review of a new perspective on CSR and its implications for the firm, governance, and democracy", Journal of Management Studies, Vol. 48 No. 4, pp. 899-931.

Schleifer, P. (2019), "Varieties of multi-stakeholder governance: selecting legitimation strategies in transnational sustainability politics", Globalizations, Vol. 16 No. 1, pp. 50-66.

Schleifer, P., Fiorini, M. and Auld, G. (2019), "Transparency in transnational governance: the determinants of information disclosure of voluntary sustainability programs", Regulation and Governance, Vol. 13 No. 4, pp. 488-506.

Schönherr, N., Findler, F. and Martinuzzi, A. (2017), "Exploring the interface of CSR and the sustainable development goals", Transnational Corporations, Vol. 24 No. 3, pp. 33-47.

Schönherr, N., Reisch, L.A., Farsang, A., Temmes, A., Tharani, A. and Martinuzzi, A. (2019), "The corporate toolbox", in Martinuzzi, A. (Ed.), Business and the Sustainable Development Goals: Measuring and Managing Corporate Impacts, Palgrave Pivot, Springer International Publishing, Cham, pp. 19-53. 
SAMPJ

13,1

Schons, L. and Steinmeier, M. (2016), "Walk the talk? How symbolic and substantive CSR actions affect firm performance depending on stakeholder proximity", Corporate Social Responsibility and Environmental Management, Vol. 23 No. 6, pp. 358-372.

Schuler, D.A. and Christmann, P. (2011), "The effectiveness of market-based social governance schemes. The case of fair trade coffee”, Business Ethics Quarterly, Vol. 21 No. 1, pp. 133-156.

Simpson, D., Power, D. and Klassen, R. (2012), "When one size does not fit all: a problem of fit rather than failure for voluntary management standards", Journal of Business Ethics, Vol. 110 No. 1, pp. 85-95.

Sippl, K. (2015), "Constructing private governance: the rise and evolution of forest, coffee, and fisheries certification. New haven, CT: Yale university press. 352 pages. ISBN: 9780300190533, $\$ 30.00$ paperback. Graeme auld. 2014”, Review of Policy Research, Vol. 32 No. 2, pp. 269-271.

Slager, R., Gond, J.P. and Moon, J. (2012), "Standardization as institutional work. The regulatory power of a responsible investment standard”, Organization Studies, Vol. 33 Nos 5/6, pp. 763-790.

Teddlie, C. and Tashakkori, A. (2010), Foundations of Mixed Methods Research: Integrating Quantitative and Qualitative Approaches in the Social and Behavioral Sciences, [Nachdr.], SAGE Publ, Los Angeles.

Teddlie, C. and Yu, F. (2017), "Mixed methods sampling", Journal of Mixed Methods Research, Vol. 1 No. 1, pp. 77-100.

Terlaak, A. (2007), "Order without law? The role of certified management standards in shaping socially desired firm behaviors", Academy of Management Review, Vol. 32 No. 3, pp. 968-985.

Terwindt, C. and Armstrong, A. (2019), "Oversight and accountability in the social auditing industry: the role of social compliance initiatives”, International Labour Review, Vol. 158 No. 2, pp. 245-272.

Tharani, A. (2019), "Measuring what matters: standardized versus customizable impact measurement tools", in Martinuzzi, A. (Ed.), Business and the Sustainable Development Goals: Measuring and Managing Corporate Impacts, Palgrave Pivot, Springer International Publishing, Cham, pp. 75-93.

Timmermans, S. and Epstein, S. (2010), "A world of standards but not a standard world: toward a sociology of standards and standardization", Annual Review of Sociology, Vol. 36 No. 1, pp. 69-89.

Tourais, P. and Videira, N. (2016), "Why, how and what do organizations achieve with the implementation of environmental management Systems? Lessons from a comprehensive review on the eco-management and audit scheme", Sustainability, Vol. 8 No. 3, p. 283.

Tschopp, D. and Nastanski, M. (2014), "The harmonization and convergence of corporate social responsibility reporting standards", Journal of Business Ethics, Vol. 125 No. 1, pp. 147-162.

van Kersbergen, K. and van Waarden, F. (2004), "Governance' as a bridge between disciplines: crossdisciplinary inspiration regarding shifts in governance and problems of governability, accountability and legitimacy", European Journal of Political Research, Vol. 43 No. 2, pp. 143-171.

Vaz, N., Fernandez-Feijoo, B. and Ruiz, S. (2016), "Integrated reporting: an international overview", Business Ethics: A European Review, Vol. 25 No. 4, pp. 577-591.

Vidal, R., Ma, Y. and Sastry, S.S. (2016), "Principal component analysis", in Vidal, R., Ma, Y. and Sastry, S. (Eds), Generalized Principal Component Analysis, Interdisciplinary Applied Mathematics, Vol. 40, Springer New York, NY, pp. 25-62.

Vigneau, L., Humphreys, M. and Moon, J. (2015), "How do firms comply with international sustainability standards? Processes and consequences of adopting the global reporting initiative", Journal of Business Ethics, Vol. 131 No. 2, pp. 469-486.

Villela, M., Bulgacov, S. and Morgan, G. (2019), "B corp certification and its impact on organizations over time”, Journal of Business Ethics, Vol. 170 No. 2.

Vogel-Pöschl, H., Martinuzzi, A. and Schönherr, N. (2020), "Evaluation unternehmerischer wirkungen auf die UN nachhaltigkeitsziele (SDGs) - werkzeuge, fallbeispiele und künftige herausforderungen”, Zeitschrift Für Evaluation, Vol. 2020 No. 2, pp. 261-290.

Waddock, S. (2008), "Building a new institutional infrastructure for corporate responsibility", Academy of Management Perspectives, Vol. 22 No. 3, pp. 87-108. 
Whitaker, S. (2018), “The natural capital protocol”, in Anderson, V. (Ed.), Debating Nature's Value: The Concept of "Natural Capital", Palgrave Pivot, 1st ed., Palgrave Macmillan, Cham, Switzerland, pp. 25-38.

Wiengarten, F., Humphreys, P., Onofrei, G. and Fynes, B. (2016), "The adoption of multiple certification standards. Perceived performance implications of quality, environmental and health and safety certifications", Production Planning and Control, Vol. 28 No. 2, pp. 131-141.

Wijen, F. (2014), "Means versus ends in opaque institutional fields. Trading off compliance and achievement in sustainability standard adoption”, Academy of Management Review, Vol. 39 No. 3, pp. 302-323.

Windolph, S.E., Harms, D. and Schaltegger, S. (2014), "Motivations for corporate sustainability management. Contrasting survey results and implementation", Corporate Social Responsibility and Environmental Management, Vol. 21 No. 5, pp. 272-285.

Witt, M.A. (2019), "De-globalization: Theories, predictions, and opportunities for international business research”, Journal of International Business Studies, Vol. 50 No. 7, pp. 1053-1077.

Zinenko, A., Rovira, M.R. and Montiel, I. (2015), "The fit of the social responsibility standard ISO 26000 within other CSR instruments", Sustainability Accounting, Management and Policy Journal, Vol. 6 No. 4, pp. 498-526.

Zwick, Y. (2015), "The sustainability code - a new approach linking economy and society towards sustainability", Global Policy, Vol. 6 No. 4, pp. 481-482.

\section{Further reading}

Adams, C.A. and Larrinaga-González, C. (2007), "Engaging with organisations in pursuit of improved sustainability accounting and performance", Accounting, Auditing and Accountability Journal, Vol. 20 No. 3, pp. 333-355.

Archel, P., Husillos, J. and Spence, C. (2011), "The institutionalisation of unaccountability: loading the dice of corporate social responsibility discourse", accounting", Organizations and Society, Vol. 36 No. 6, pp. 327-343.

Bebbington, J. and Gray, R. (2001), "An account of sustainability: failure, success and a reconceptualization", Critical Perspectives on Accounting, Vol. 12 No. 5, pp. 557-587.

Jamali, D. (2010), "MNCs and international accountability standards through an institutional lens: evidence of symbolic conformity or decoupling", Journal of Business Ethics, Vol. 95 No. 4, pp. 617-640.

Johnson, M.P. and Schaltegger, S. (2016), "Two decades of sustainability management tools for SMEs. How far have we come?", Journal of Small Business Management, Vol. 54 No. 2, pp. 481-505.

Morrow, D. and Rondinelli, D. (2002), “Adopting corporate environmental management systems", European Management Journal, Vol. 20 No. 2, pp. 159-171.

Pruett, D., Merk, J., Zeldenrust, I. and de Haan, E. (2005), "Looking for a quick fix: how weak social auditing is keeping workers in sweatshops, Amsterdam", available at: http://eprints.lse.ac.uk/56743/.

Wagner, M. (2009), "Innovation and competitive advantages from the integration of strategic aspects with social and environmental management in European firms", Business Strategy and the Environment, Vol. 18 No. 5, pp. 291-306.

\section{Corresponding author}

Norma Schönherr can be contacted at: norma.schoenherr@wu.ac.at

For instructions on how to order reprints of this article, please visit our website:

www.emeraldgrouppublishing.com/licensing/reprints.htm

Or contact us for further details: permissions@emeraldinsight.com 